\title{
A bibliometric analysis of Crossref agritourism literature indexed in Web of Science
}

\author{
Darko Dimitrovski $^{{ }^{*}}$, Miljan Leković ${ }^{1}$, Veronika Joukes ${ }^{2}$ \\ ${ }^{1}$ University of Kragujevac, Faculty of Hotel Management and Tourism in Vrnjačka Banja, \\ Serbia \\ ${ }^{2}$ University of Trás-os-Montes and Alto Douro, and Centre for Transdisciplinary \\ Development Studies (CETRAD), Portugal
}

\begin{abstract}
Agritourism has received growing academic attention over the recent decades. Thus, the current focus on the state of academic knowledge on agritourism provides further insight into the development of thought in the field and a better understanding of the main issues of importance for the academic community in this area. To secure the understanding of the most frequent topics within agritourism literature, the sample of 21 Crossref journals indexed in Web of Science was defined. A bibliometric and keyword analysis served as valuable instruments to assess the current trends within the topic and to predict the future direction of agritourism research. The results of the implemented analysis suggest that the scientific journal of Tourism Management is the most influential journal to spread knowledge regarding agritourism, while Carla Barbieri is recognised as the most influential author in the field. The recently increased interest in rurality on a global scale emphasises the need for more agritourism studies that will be capable of providing valuable guidelines for agritourism providers, tourists, and destination managers.
\end{abstract}

Keywords: bibliometric analysis, agritourism, academic literature

JEL classification: Z30, Z32

\section{Bibliometrijska analiza Crossref literature na temu agroturizma indeksirane $u$ Web of Science-u}

Sažetak: Poslednjih decenija agroturizam dobija sve veću akademsku pažnju. Samim tim, istraživanje trenutnog akademskog znanja na temu agroturizma pruža uvid u razvoj same oblasti i omogućava dalje razumevanje glavnih pitanja od značaja za akademsku zajednicu. Da bi se osiguralo bolje razumevanje znanja na temu agroturizma definisan je uzorak od 21 Crossref časopisa indeksiranih u Web of Science-u. Bibliometrijska i analiza ključnih reči poslužile su kao koristan instrument za procenu trenutnih trendova unutar ispitivane teme i

* darko.dimitrovski@kg.ac.rs

** Paper was supported by the R\&D Project INNOVINE \& WINE - Vineyard and Wine Innovation Platform - Operation NORTE -01-0145-FEDER-000038, co-funded by the European and Structural Investment Funds (FEDER) and by Norte 2020 (Programa Operacional Regional do Norte 2014/2020), European Structural and Investment Funds in the FEDER component, through the Operational Competitiveness and Internationalization Programme (COMPETE 2020) [Project No. 006971 (UID/SOC/04011)], and national funds, through the FCT - Portuguese Foundation for Science and Technology under the project UID/SOC/04011/2013. 
za predviđanje budućeg smera istraživanja na temu agroturizma. Rezultati sprovedenih analiza ukazuju na to da naučni časopis Tourism Management ima najuticajnije mesto u širenju znanja na temu agroturizma, dok je autor Carla Barbieri prepoznata kao najuticajniji autor u okviru analizirane oblasti. Nedavno rastuće interesovanje za ruralna područja na globalnom nivou povećava potrebu za daljim istraživanjima u oblasti agroturizma, koja će biti u stanju da daju dragocene smernice pružaocima usluga u oblasti agroturizma, turistima i destinacijskim menadžerima.

Ključne reči: biblometrijska analiza, agroturizam, akademska literatura JEL klasifikacija: Z30, Z32

\section{Introduction}

A growing demand for the countryside and the appeal of rural living (Gao et al., 2014), especially expressed by urban population, formed the point of departure for a rapid increase in the demand for agritourism (Wicks \& Merrett, 2003). For a long period of time, agriculture has been a dominant economic activity in rural areas (Simonović et al., 2017; Mihailović et al., 2018), but with the growing intensity of the globalisation process (Pjanić et al., 2018), a negative correlation between rural demography and property structure has been exposed (Carmichael, 2005; Blažević et al., 2018). In these circumstances, tourism is seen as the way of solving the problem since it has the capacity to promote rural communities and provide them new impetus for sustainable development (Brankov et al., 2017; Mandarić et al., 2017; Petrović et al., 2017). Implementing a sound tourism development in rural areas could provide sustainable future for these vulnerable regions dependable upon agricultural production. Rural areas possess this unique opportunity to attract tourists willing to establish a connection with their "cultural, historic, ethnic and geographical roots" (Dimitrovski et al., 2012). The tourism supply side is responding to this ongoing demand for rural experiences through the creation of new tourism products which are linked to the rural environment, such as agritourism (Horng \& Tsai, 2012). As a result of the attractiveness of their landscape and healthy and calm environment, rural regions have become an appealing product consumed by tourists (Carmichael, 2005).

There is increasing attention given to agritourism in academic writings. The topic of agritourism is seen as a novel co-creative approach to rurality. The academic community follows the increasing interest in rural areas, influencing the topic to appear more frequently on tourism research agendas (Vuković, 2017). This paper provides a bibliometric analysis of the 'agritourism' literature. The aim of the study was to examine all the Crossref literature sources having 'agritourism' as a keyword, with the idea to understand the current tendencies within the topic, thus, providing a solid basis for a deeper understanding of the progress of the academic knowledge regarding agritourism. The research results will allow us to formulate the most important streams of the agritourism academic knowledge published in Web of Science indexed scientific journals.

\section{Agritourism literature review}

The concept of agritourism has been present in tourism literature for a considerable period of time. However, in the last few decades agritourism attracted a growing interest year in year out. Nevertheless, "limited attention has been given to understand the key features that define agritourism as a concept” (Flanigan et al., 2014). One of the main problems is that the agritourism concept is usually associated and used interchangeably with rural tourism (Phillip et al., 2010), or other tourism activities in rural areas such as farm tourism (Zhang et al., 2009). The use of the terms in different geographical (Phillip et al., 2010; Flanigan et al., 26 
2014; Lapan \& Barbieri, 2014), political and social backgrounds (Phillip et al., 2010; Tew \& Barbieri, 2012; Flanigan et al., 2014; Lapan \& Barbieri, 2014) contributes to the confusion. Moreover, tourism literature is usually faced with the challenge that different terms with the same meaning are used, such as "onfarm tourism”, "agritourism”, "agrotourism” (Dubois et al., 2017). Ongoing dilemmas around the agritourism meaning in the academic and nonacademic community are mostly due to geopolitical contexts associated with government policies (McGehee et al., 2007; Tew \& Barbieri, 2012; Arroyo et al., 2013). Overall, the terminology issue is loaded with confusion, especially when authors do not provide the agritourism definition in their research (Flanigan et al., 2014).

Although there is not a single definition of agritourism (Barbieri, 2013), in order to acknowledge differences and similarities between the perception of the concept, a few explanations of agritourism follow. Tew and Barbieri (2012, p. 216) describe agritourism as "nearly any activity in which a visitor to the farm or other agricultural setting contemplates the farm landscape or participates in an agricultural process for recreation or leisure purposes". Gao et al. (2014, p. 367) have defined agritourism as "visiting a working farm or any other agricultural setting for enjoyment, education, or active involvement in operation's activities". Other definitions concentrate on the undertaken activities. Arroyo et al. (2013, p. 45) focus on the same topics in their definition: agritourism "should include staged or authentic agricultural activities or processes occurring in working agricultural facilities either for entertainment or educational purposes”. Govindasamy and Kelley (2014, p. 121) introduce a marketing perspective in the definition: agritourism is an "agriculturally based direct marketing operation or educational experience, such as pick-your-own farm, agricultural fairs/festivals and school field trips, that brings visitors to a farm or a ranch”.

A wide range of definitions (Flanigan et al., 2014) implies a "complex and confusing picture" (Phillip et al., 2010, p. 754). Thus, the conclusion of the above proposed definitions is that agritourism encompasses a variety of activities which are in a way similar, but in fact have essential differences. Misunderstandings regarding any agritourism definition are mostly related to the "relationship tourist/working farm, the type of direct or indirect contact with agriculture provided to the tourist and the authenticity of the experience in terms of actual engagement in farm tasks" (Phillip et al., 2010). It should be noted that only a few authors (Ollenburg \& Buckley, 2007; Barbieri \& Mahoney, 2009) insist on a working farm background for agritourism activities. McGehee (2007, p. 111), for example, states that agritourism entails all "rural enterprises which incorporate both a working farm environment and a commercial tourism component”. In this way, agritourism activities appear in a wide variety of forms, "including farm stays, bed and breakfasts, pick-your-own products offers, agricultural festivals, farm tours for children, or hayrides” (McGehee, 2007).

Phillip et al. (2010) could be seen as pioneers in this field, devoting a significant effort to propose an agritourism model based on the above-mentioned features, which was empirically tested in numerous researches in different political, social and geographical contexts (Arroyo et al., 2013; Flanigan et al., 2014; Dubois et al., 2017) and, besides gaining considerable validity, received some remarks.

\section{Methodology}

This study has implemented a bibliometric analysis using Harzing's Publish and Perish bibliometric software and a keyword analysis, presenting the results through the word cloud method. The sample used for the bibliometric and keyword analysis consists of 21 articles published in tourism and hospitality journals which are indexed in Web of Science Master Journal List for Social Sciences. The search for the articles was deployed using the terms agritourism and agri-tourism as key words within the Crossref references. The Publish and 
Perish bibliometric analysis has separated 13, i.e. 8 journal articles using agritourism i.e. agri-tourism as a keyword, respectively. The analysis was not limited with specific period of time. In addition, the citation frequency of the chosen journal articles has been examined with the idea to determine the most influential journal articles and authors in the field of agritourism.

\section{Results and discussion}

In order to reveal the structure and characteristics of the sample, Table 1 was prepared as a summary of 21 chosen papers.

Table 1: The structure and characteristics of the sample

\begin{tabular}{|c|c|c|c|c|}
\hline Author(s) & Title & Journal & Region & Method(s) \\
\hline$\frac{\text { Barbieri, C. }}{\underline{(2013)}}$ & $\begin{array}{l}\text { “Assessing the } \\
\text { sustainability of } \\
\text { agritourism in the } \\
\text { US: A comparison } \\
\text { between agritourism } \\
\text { and other farm } \\
\text { entrepreneurial } \\
\text { ventures” }\end{array}$ & $\begin{array}{l}\text { Journal of } \\
\text { Sustainable } \\
\text { Tourism }\end{array}$ & $\begin{array}{l}\text { North America, } \\
\text { U.S. and } \\
\text { Canada }\end{array}$ & $\begin{array}{l}\text { Online survey } \\
\text { (descriptive } \\
\text { statistics) }\end{array}$ \\
\hline$\frac{\text { Barbieri, C. }}{\underline{(2019)}}$ & $\begin{array}{l}\text { “Agritourism } \\
\text { research: a } \\
\text { perspective article" }\end{array}$ & $\begin{array}{l}\text { Tourism } \\
\text { Review }\end{array}$ & $\begin{array}{l}\text { No specific } \\
\text { region }\end{array}$ & $\begin{array}{l}\text { No specific } \\
\text { method }\end{array}$ \\
\hline$\frac{\frac{\text { Doh, K., Park, }}{\text { S., \& Kim, D. Y. }}}{\underline{(2017)}}$ & $\begin{array}{l}\text { “Antecedents and } \\
\text { consequences of } \\
\text { managerial behavior } \\
\text { in agritourism” }\end{array}$ & $\begin{array}{c}\text { Tourism } \\
\text { Management }\end{array}$ & $\begin{array}{c}\text { Midwestern } \\
\text { United States, } \\
\text { U.S. }\end{array}$ & $\begin{array}{c}\text { Online survey } \\
\text { (Partial Least } \\
\text { Square - PLS } \\
\text { analysis) }\end{array}$ \\
\hline$\frac{\frac{\text { Tew, C., \& }}{\text { Barbieri, C. }}}{\underline{(2012)}}$ & $\begin{array}{l}\text { “The perceived } \\
\text { benefits of } \\
\text { agritourism: The } \\
\text { provider's } \\
\text { perspective” } \\
\end{array}$ & $\begin{array}{c}\text { Tourism } \\
\text { Management }\end{array}$ & Missouri, U.S. & $\begin{array}{l}\text { Survey with } \\
\text { questionnaire } \\
\text { (Multiple linear } \\
\text { regression) }\end{array}$ \\
\hline $\begin{array}{c}\text { Phillip, S., } \\
\frac{\text { Hunter, C., \& }}{\text { Blackstock, K. }} \\
\frac{(2010)}{}\end{array}$ & $\begin{array}{l}\text { "A typology for } \\
\text { defining agritourism" }\end{array}$ & $\begin{array}{c}\text { Tourism } \\
\text { Management }\end{array}$ & $\begin{array}{l}\text { No specific } \\
\text { region }\end{array}$ & $\begin{array}{l}\text { No specific } \\
\text { method }\end{array}$ \\
\hline$\frac{\text { Canovi, M. }}{\underline{(2019)}}$ & $\begin{array}{c}\text { "Resistance to } \\
\text { agritourism } \\
\text { diversification: An } \\
\text { analysis of winery } \\
\text { owners' identities" }\end{array}$ & $\begin{array}{c}\text { Tourism } \\
\text { Management } \\
\text { Perspectives }\end{array}$ & Langhe, Italy & $\begin{array}{l}\text { Interviews with } \\
\text { questionnaire } \\
\text { (qualitative } \\
\text { analysis) }\end{array}$ \\
\hline $\begin{array}{l}\frac{\text { Choo, H., \& }}{\text { Petrick, J. F. }} \\
\underline{(2014)}\end{array}$ & $\begin{array}{l}\text { "Social interactions } \\
\text { and intentions to } \\
\text { revisit for agritourism } \\
\text { service encounters" }\end{array}$ & $\begin{array}{c}\text { Tourism } \\
\text { Management }\end{array}$ & Texas, U.S. & $\begin{array}{c}\text { Onsite survey } \\
\text { with } \\
\text { questionnaire } \\
\text { (factor analyses) } \\
\end{array}$ \\
\hline$\frac{\frac{\text { Hill, R., Loomis, }}{\text { J., Thilmany, D., }}}{\frac{\text { \& Sullins, M. }}{(2014)}}$ & $\begin{array}{l}\text { "Economic values of } \\
\text { agritourism to } \\
\text { visitors: a multi- } \\
\text { destination hurdle } \\
\text { travel cost model of } \\
\text { demand" }\end{array}$ & $\begin{array}{l}\text { Tourism } \\
\text { Economics }\end{array}$ & Colorado, U.S. & $\begin{array}{l}\text { Online survey and } \\
\text { secondary data } \\
\text { from the US } \\
\text { Census and the } \\
\text { natural amenities } \\
\text { index (Travel } \\
\text { Cost Method- } \\
\text { TCM; a hurdle } \\
\text { model) }\end{array}$ \\
\hline
\end{tabular}


Dimitrovski, D. et al. - A bibliometric analysis of Crossref agritourism literature indexed in Web of ScienceHotel and Tourism Management, 2019, Vol. 7, No. 2: 25-37.

\begin{tabular}{|c|c|c|c|c|}
\hline$\frac{\frac{\text { Arroyo, C. G., }}{\text { Barbieri, C., \& }}}{\frac{\text { Rich, S. R. }}{\underline{(2013)}}}$ & $\begin{array}{c}\text { “Defining } \\
\text { agritourism: A } \\
\text { comparative study of } \\
\text { stakeholders' } \\
\text { perceptions in } \\
\text { Missouri and North } \\
\text { Carolina” } \\
\end{array}$ & $\begin{array}{c}\text { Tourism } \\
\text { Management }\end{array}$ & $\begin{array}{c}\text { Missouri and } \\
\text { North Carolina, } \\
\text { U.S. }\end{array}$ & $\begin{array}{l}\text { Survey with } \\
\text { questionnaire } \\
\text { (ANOVA, Chi- } \\
\text { square tests) }\end{array}$ \\
\hline $\begin{array}{l}\underline{\text { Ainley, S., \& }} \\
\text { Kline, C. (2014) }\end{array}$ & $\begin{array}{l}\text { “Moving beyond } \\
\text { positivism: Reflexive } \\
\text { collaboration in } \\
\text { understanding } \\
\text { agritourism across } \\
\text { North American } \\
\text { boundaries" }\end{array}$ & $\begin{array}{l}\text { Current } \\
\text { Issues in } \\
\text { Tourism }\end{array}$ & $\begin{array}{c}\text { North America, } \\
\text { U.S. }\end{array}$ & $\begin{array}{l}\text { Qualitative study } \\
\text { (interpretative } \\
\text { phenomenological } \\
\text { analysis and } \\
\text { appreciative } \\
\text { inquiry) }\end{array}$ \\
\hline $\begin{array}{l}\frac{\text { Nickerson, N. P., }}{\text { Black, R. J., \& }} \\
\frac{\text { McCool, S. F. }}{(2001)}\end{array}$ & $\begin{array}{l}\text { “Agritourism: } \\
\text { Motivations behind } \\
\text { farm/ranch business } \\
\text { diversification” }\end{array}$ & $\begin{array}{l}\text { Journal of } \\
\text { Travel } \\
\text { Research }\end{array}$ & Montana, U.S. & $\begin{array}{c}\text { Survey with } \\
\text { questionnaire } \\
\text { (ANOVA, cluster } \\
\text { analysis, Chi- } \\
\text { square tests of } \\
\text { independence) }\end{array}$ \\
\hline$\frac{\text { Gao, J., Barbieri, }}{\frac{\text { C., \& Valdivia, }}{\underline{\text { C. }(2014)}}}$ & $\begin{array}{c}\text { “Agricultural } \\
\text { Landscape } \\
\text { Preferences: } \\
\text { Implications for } \\
\text { Agritourism } \\
\text { Development” }\end{array}$ & $\begin{array}{l}\text { Journal of } \\
\text { Travel } \\
\text { Research }\end{array}$ & $\begin{array}{c}\text { Missouri, } \\
\text { Pennsylvania, } \\
\text { and Texas, U.S. }\end{array}$ & $\begin{array}{l}\text { Online survey } \\
\text { (MANOVA) }\end{array}$ \\
\hline$\frac{\text { Rong-Da Liang, }}{\underline{\text { A. (2017) }}}$ & $\begin{array}{l}\text { "Considering the role } \\
\text { of agritourism co- } \\
\text { creation from a } \\
\text { service-dominant } \\
\text { logic perspective” }\end{array}$ & $\begin{array}{c}\text { Tourism } \\
\text { Management }\end{array}$ & $\begin{array}{l}\text { A-Lian District } \\
\text { of Kaohsiung } \\
\text { City (Taiwan) }\end{array}$ & $\begin{array}{l}\text { Interviews with } \\
\text { questionnaire } \\
\text { (regression } \\
\text { analysis) }\end{array}$ \\
\hline$\frac{\text { McGehee, N. G., }}{\frac{\text { \& Kim, K. }}{(2004)}}$ & $\begin{array}{l}\text { "Motivation for agri- } \\
\text { tourism } \\
\text { entrepreneurship" }\end{array}$ & $\begin{array}{l}\text { Journal of } \\
\text { Travel } \\
\text { Research }\end{array}$ & Virginia, U.S. & $\begin{array}{l}\text { Survey with } \\
\text { questionnaire } \\
\text { (MANOVA) }\end{array}$ \\
\hline $\begin{array}{l}\frac{\text { McGehee, N. G., }}{\text { Kim, K., \& }} \\
\frac{\text { Jennings, G. R. }}{(2007)}\end{array}$ & $\begin{array}{c}\text { "Gender and } \\
\text { motivation for agri- } \\
\text { tourism } \\
\text { entrepreneurship" }\end{array}$ & $\begin{array}{c}\text { Tourism } \\
\text { Management }\end{array}$ & Virginia, U.S. & $\begin{array}{l}\text { Survey with } \\
\text { questionnaire } \\
\text { (MANOVA) }\end{array}$ \\
\hline$\frac{\text { Daugstad, K., \& }}{\frac{\text { Kirchengast, C. }}{\underline{(2013)}}}$ & $\begin{array}{l}\text { "Authenticity and the } \\
\text { pseudo-backstage of } \\
\text { agri-tourism” }\end{array}$ & $\begin{array}{l}\text { Annals of } \\
\text { Tourism } \\
\text { Research }\end{array}$ & $\begin{array}{l}\text { Bregenzerwald } \\
\text { (Austria) and } \\
\text { Valdres } \\
\text { (Norway) }\end{array}$ & $\begin{array}{l}\text { Semi-structured } \\
\text { qualitative } \\
\text { interviews } \\
\text { (qualitative } \\
\text { analysis) } \\
\end{array}$ \\
\hline$\frac{\frac{\text { Hegarty, C., \& }}{\text { Przezborska, L. }}}{\underline{(2005)}}$ & $\begin{array}{l}\text { "Rural and } \\
\text { agri-tourism as a tool } \\
\text { for reorganising rural } \\
\text { areas in old and new } \\
\text { member states - a } \\
\text { comparison study of } \\
\text { Ireland and Poland" }\end{array}$ & $\begin{array}{l}\text { International } \\
\text { Journal of } \\
\text { Tourism } \\
\text { Research }\end{array}$ & $\begin{array}{l}\text { Ireland and } \\
\text { Poland }\end{array}$ & $\begin{array}{l}\text { Interviews } \\
\text { (comparative } \\
\text { analysis) }\end{array}$ \\
\hline$\frac{\text { Embacher, H. }}{\underline{(1994)}}$ & $\begin{array}{l}\text { "Marketing for } \\
\text { Agri-tourism in } \\
\text { Austria: Strategy and } \\
\text { realisation in a highly } \\
\text { developed tourist } \\
\text { destination" } \\
\end{array}$ & $\begin{array}{l}\text { Journal of } \\
\text { Sustainable } \\
\text { Tourism }\end{array}$ & Austria & $\begin{array}{l}\text { Secondary data } \\
\text { analysis }\end{array}$ \\
\hline
\end{tabular}


Dimitrovski, D. et al. - A bibliometric analysis of Crossref agritourism literature indexed in Web of ScienceHotel and Tourism Management, 2019, Vol. 7, No. 2: 25-37.

\begin{tabular}{|c|c|c|c|c|}
\hline $\begin{array}{l}\frac{\text { Koutsouris, A., }}{\text { Gidarakou, I., }} \\
\frac{\text { Grava, F., \& }}{\text { Michailidis, A. }} \\
\underline{(2014)}\end{array}$ & $\begin{array}{c}\text { “The phantom of } \\
\text { (agri) tourism and } \\
\text { agriculture } \\
\text { symbiosis? A Greek } \\
\text { case study” }\end{array}$ & $\begin{array}{c}\text { Tourism } \\
\text { Management } \\
\text { Perspectives }\end{array}$ & Corinth, Greece & $\begin{array}{l}\text { Interviews with } \\
\text { questionnaire } \\
\text { (categorical } \\
\text { regression model) }\end{array}$ \\
\hline$\frac{\frac{\text { Contini, C., }}{\text { Scarpellini, P., \& }}}{\frac{\text { Polidori, R. }}{(2009)}}$ & $\begin{array}{l}\text { "Agri-tourism and } \\
\text { rural development: } \\
\text { The Low-Valdelsa } \\
\text { case, Italy" }\end{array}$ & $\begin{array}{l}\text { Tourism } \\
\text { Review }\end{array}$ & Tuscany, Italy & $\begin{array}{c}\text { Survey with } \\
\text { questionnaire } \\
\text { (Input-Output } \\
\text { model) }\end{array}$ \\
\hline$\frac{\frac{\text { Giaccio, V., }}{\text { Giannelli, A., \& }}}{\frac{\text { Mastronardi, L. }}{(2018)}}$ & $\begin{array}{l}\text { "Explaining } \\
\text { determinants of agri- } \\
\text { tourism income: } \\
\text { Evidence from Italy" }\end{array}$ & $\begin{array}{l}\text { Tourism } \\
\text { Review }\end{array}$ & Italy & $\begin{array}{l}\text { Multivariate } \\
\text { regression model }\end{array}$ \\
\hline
\end{tabular}

Source: Prepared by the authors

The abstracts of the above presented works already reveal that a wide range of topics are tackled in the field of agritourism: starting with defining agritourism and its authenticity, analysing its benefits and influence on the development and reorganisation of rural areas, examining its promotion strategies, understanding the motives of men and women to undertake entrepreneurial activities, unveiling the impact of social interactions on agritourists' satisfaction, and finally to assessing agritourism sustainability.

In more than a half of the analysed articles, the research was conducted in the US; in one third of them it was undertaken in Europe followed by Canada and Taiwan with one research per country. Two studies did not relate to a specific area. A survey questionnaire (online survey/onsite survey/interviews) was used in $3 / 4$ or $76 \%$ of the studies. After collecting the respondents' answers, the authors most commonly applied the following analysis: analysis of variance (ANOVA), multivariate analysis of variance (MANOVA), regression analysis, Chisquare tests and qualitative analysis.

In order to examine the distribution of the selected papers across the journals, Table 2 was prepared.

Table 2: The journal distribution of the papers

\begin{tabular}{|c|c|}
\hline Journal & Number of papers \\
\hline Tourism Management & 7 \\
\hline Journal of Travel Research & 3 \\
\hline Tourism Review & 3 \\
\hline Journal of Sustainable Tourism & 2 \\
\hline Tourism Management Perspectives & 2 \\
\hline Annals of Tourism Research & 1 \\
\hline Current Issues in Tourism & 1 \\
\hline International Journal of Tourism Research & 1 \\
\hline Tourism Economics & 1 \\
\hline Total & 21 \\
\hline
\end{tabular}

Source: Prepared by the authors

The data indicate that a third of the analysed papers on the topic of agritourism were published in the scientific journal of Tourism Management ( 7 articles), which clearly 30 
indicates the high degree of concentration of papers on agritourism in this journal. The second place regarding the number of the published papers is shared between Journal of Travel Research (3) and Tourism Review, while in the case of the remaining journals a relatively even distribution of papers could be noticed (2 or 1 ).

It is also important to emphasise that out of the three papers published in the scientific journal of Tourism Review, two have been published very recently (2018 and 2019), pointing out that an even larger share of agritourism papers in this journal can be expected in future, which would consequently increase its influence on the development of scientific thought in this field.

Table 3 gathers the keywords that are repeated at least three or more times, with the aim of determining which keywords occur most frequently in agritourism papers, or which issues capture the attention of researchers within the analysed area.

Table 3: The repetitive keywords within the dataset

\begin{tabular}{|c|c|}
\hline Keyword & $\begin{array}{c}\text { Number of } \\
\text { repetition }\end{array}$ \\
\hline agritourism & 18 \\
\hline rural tourism & 4 \\
\hline farm tourism & 4 \\
\hline entrepreneurship & 3 \\
\hline tourism & 3 \\
\hline authenticity & 3 \\
\hline rural areas & 3 \\
\hline Italy & 3 \\
\hline
\end{tabular}

Source: Prepared by the authors

First, it is important to note that the article of Nickerson's et al. (2001) did not provide any keywords, which is why Table 3 was elaborated based on the remaining 20 articles. Second, keywords not only make the search for papers in indexed databases easier, but also indicate the trends in agritourism research.

The results of the bibliometric analysis reveal that in addition to the keyword agritourism and its variants rural tourism, farm tourism and tourism, the following issues are in the focus of the researchers: entrepreneurship, authenticity, rural areas and Italy. It is not surprising that Italy is mentioned three times as it is a well-known winegrowing area, where organised visits to wineries are usually perceived as a form of agritourism. Apart from rural areas which are a rather obvious geographical association, the most interesting research perspectives boil down to entrepreneurship and authenticity. In general, it must be said that the keywords point into a rather traditional research direction.

In order to provide a visual representation of the most frequently cited keywords and most frequent topics within the analysed papers, the word cloud of the keywords was prepared (Figure 1). The most frequently cited keywords are shown in larger letters and occupy a central position in the word cloud. 
Figure 1: Word cloud of the keywords

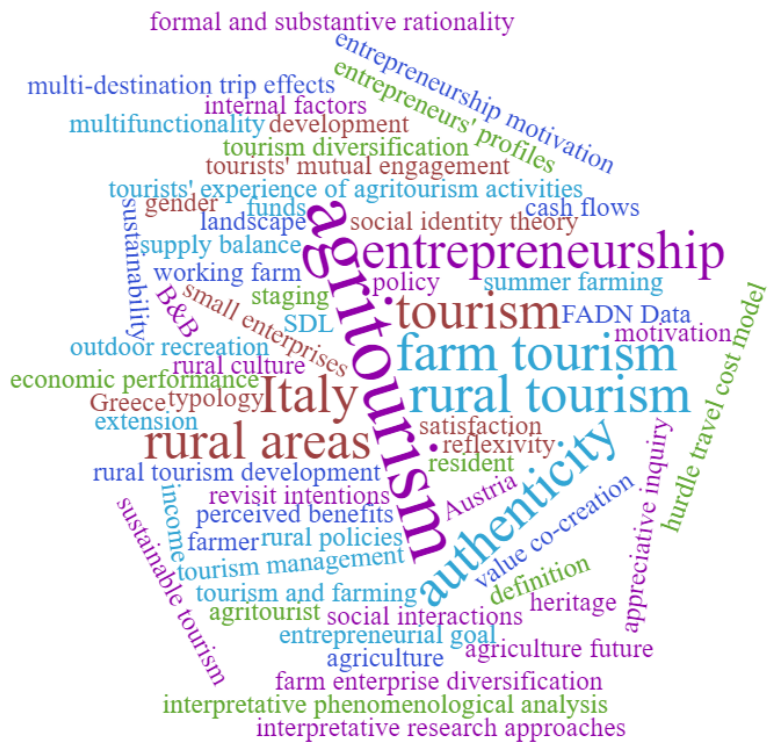

Source: Prepared by the authors

In order to determine the importance and contribution of individual works to the development of agritourism knowledge and to examine the distribution of citations across the papers, the Publish or Perish software package was used (Table 4). It is important to point out that, according to Nisonger's (2000) argument, the exclusion of autocytes is not a prerequisite for conducting a quality citation analysis. Therefore, heterocytes and selfcitations were considered.

Table 4: Distribution of the citations across the selected papers

\begin{tabular}{|c|c|c|c|}
\hline Author(s) & Crossref & Cites per year & Cites per author \\
\hline Barbieri (2013) & 44 & 7.33 & 44 \\
\hline Barbieri (2019) & 0 & 0 & 0 \\
\hline Doh et al. (2017) & 3 & 1.5 & 45 \\
\hline Tew \& Barbieri (2012) & 89 & $\mathbf{1 2 . 7 1}$ & 33 \\
\hline Phillip et al. (2010) & $\mathbf{1 0 0}$ & $\mathbf{1 1 . 1 1}$ & 0 \\
\hline Canovi (2019) & 0 & 0 & 28 \\
\hline Choo \& Petrick (2014) & 56 & $\mathbf{1 1 . 2}$ & 1 \\
\hline Hill et al. (2014) & 4 & 0.8 & 17 \\
\hline Arroyo et al. (2013) & 51 & 8.5 & 35 \\
\hline Ainley \& Kline (2014) & 7 & 1.17 & 10 \\
\hline Nickerson et al. (2001) & $\mathbf{1 0 4}$ & 5.78 & 6 \\
\hline Gao et al. (2013) & 31 & 3.17 & 70 \\
\hline Rong-Da Liang (2017) & 6 & 9.33 & 26 \\
\hline McGehee \& Kim (2004) & $\mathbf{1 4 0}$ & 6.5 & 23 \\
\hline McGehee et al. (2007) & 78 & 7.67 & 20 \\
\hline Daugstad \& Kirchengast (2013) & 46 & 2.79 & 31 \\
\hline Hegarty \& Przezborska (2005) & 39 & 1.24 & 4 \\
\hline Embacher (1994) & 31 & 3 & 5 \\
\hline Koutsouris et al. (2014) & 15 & 1.4 & 1 \\
\hline Contini et al. (2009) & 14 & 4 & \\
\hline Giaccio et al. (2018) & 4 & & \\
\hline
\end{tabular}

Source: Prepared by the authors 
The analysed papers were cited 862 times, according to data gathered from Publish or Perish software package. Not having taken into consideration two papers that did not record any citations, the average citation per paper was 45.37. There were no quotations for Barbieri (2019) and Canovi (2019) since their articles were published just a few months ago. Among the papers analysed, the most cited papers were McGehee and Kim (2004) with 140 citations, Nickerson et al. (2001) with 104 citations and Phillip et al. (2010) with 100 citations.

However, as the number of citations depends, among other things, on the year of paper publication, a more relevant indicator of the impact of the work is the number of citations per year of availability of the work. By this criterion, the most influential works in the field of agritourism are Tew and Barbieri (2012) with 12.71 citations per year, Choo and Petrick (2014) with 11.2 citations per year and Phillip et al. (2010) with 11.11 citations per year.

The last column of Table 4 also calculates the number of citations per author for each individual work. According to this criterion, McGehee and Kim (2004) with 70 citations per author, Tew and Barbieri (2012) with 45 citations per author, and Barbieri (2013) with 44 citations per author are in the lead. Additional analysis has revealed that Carla Barbieri is the most influential author in the field of agritourism with 5 published works and a total of 116 citations.

In addition, the same software package allowed understanding the contributions of individual papers and individual authors to the development of the research area, analysing the impact of each journal. Thus, the distribution of citations across journals was observed as a more relevant indicator of the impact of journals in comparison to the number of papers published per journal (Table 5).

Table 5: Distribution of the citations across the journals

\begin{tabular}{|c|c|}
\hline Journal & Crossref \\
\hline Tourism Management & 383 \\
\hline Journal of Travel Research & 275 \\
\hline Journal of Sustainable Tourism & 75 \\
\hline Annals of Tourism Research & 46 \\
\hline International Journal of Tourism Research & 39 \\
\hline Tourism Review & 18 \\
\hline Tourism Management Perspectives & 15 \\
\hline Current Issues in Tourism & 7 \\
\hline Tourism Economics & 4 \\
\hline Total & 862 \\
\hline
\end{tabular}

Source: Prepared by the authors

According to the applied criterion, the scientific journal of Tourism Management has the most significant influence on the development of agritourism knowledge with 383 citations, followed by the Journal of Travel Research with 275 citations. Both of them make up for $76.33 \%$ of the total number of citations. The dominant role of the mentioned journals is confirmed by the fact that these journals have published almost half of the analysed papers about agritourism. On the other hand, among the journals covered by the analysis, the smallest contribution to the development of the discussed research area is provided by Tourism Economics with 4 citations and one published paper. 


\section{Conclusion}

The conducted bibliometric analysis was a valuable exercise to understand the current state of the art in the agritourism academic thought, and also to predict future directions of the academic interest in agritourism topics. The geographical distribution favours the Western world (including the US, Canada and Europe), with special interest in agritourism development in Italy. The articles were usually based on empirical studies, with a wide range of statistical analyses (ANOVA, MANOVA, regression analysis, Chi-square tests and others). The most influential journal in the field is the scientific journal of Tourism Management which includes the majority of the sample's journal articles and citations. According to the implemented bibliometric analysis that considers citations as a relevant criterion, the most influential work was done by Tew and Barbieri (2012), and their article "The perceived benefits of agritourism: The provider's perspective", while the most influential author in the field of agritourism is Carla Barbieri with 5 published works and 116 citations. Finally, the keyword analysis has revealed a rather traditional focus on the topics of rurality and tourism (rural tourism, farm tourism and rural areas), followed by entrepreneurship and authenticity.

The contribution of the current study arises as a result of a unique approach that deploys bibliometric analysis of the existing agritourism research. Since there is only a limited number of studies focusing on the broader understanding of the progress of agritourism academic knowledge, the conducted study stimulates the interest in the topic by providing the overview of most significant journals, topics, papers and authors in the field. The identification of the most influential streams of agritourism knowledge reveal, on the one hand, the already identified and studied agritourism topics and, on the other, novel areas of significant scientific interest that could be studied in future. In this way, the academic discussion around the issue of agritourism receives wider visibility consequently arising both academic and practical interest.

The limitation of the study is related to the fact that the bibliometric analysis has been limited to Crossref references, and only directed to journals indexed in the Web of Science. Future research could provide an in-depth bibliometric analysis that considers both Scopus and Web of Science journal articles.

\section{References}

1. Ainley, S., \& Kline, C. (2014). Moving beyond positivism: Reflexive collaboration in understanding agritourism across North American boundaries. Current Issues in Tourism, 17(5), 404-413. https://doi.org/10.1080/13683500.2012.750281

2. Arroyo, C. G., Barbieri, C., \& Rich, S. R. (2013). Defining agritourism: A comparative study of stakeholders' perceptions in Missouri and North Carolina. Tourism Management, 37, 39-47. https://doi.org/10.1016/j.tourman.2012.12.007

3. Barbieri, C. (2013). Assessing the Sustainability of Agritourism in the US: A comparison between agritourism and other farm entrepreneurial ventures. Journal of Sustainable Tourism, 21(2), 252-270. https://doi.org/10.1080/09669582.2012.685174

4. Barbieri, C. (2019). Agritourism research: a perspective article. Tourism Review. https://doi.org/10.1108/TR-05-2019-0152

5. Barbieri, C., \& Mahoney, E. (2009). Why is diversification an attractive farm adjustment strategy? Insights from Texas farmers and ranchers. Journal of Rural Studies, 25(1), 5866. https://doi.org/10.1016/j.jrurstud.2008.06.001

6. Blažević, M., Peters, K., \& Chen, G. (2018). Developing rural tourism in minority ethnic villages: Zlot and Xiaocang She Ethnic Township. Menadžment u hotelijerstvu i turizmu 
Dimitrovski, D. et al. - A bibliometric analysis of Crossref agritourism literature indexed in Web of ScienceHotel and Tourism Management, 2019, Vol. 7, No. 2: 25-37.
- Hotel
and
Tourism
Management, 6(2),
71-78.

https://doi.org/10.5937/menhottur1802079B

7. Brankov, J., Petrović, M., Radovanović, M., Tretiakova, T., \& Syromiatnikova, Y. (2017). Geography and environment - Analysis of indicators of sustainable development of tourism. International Journal of Cognitive Research in Science, Engineering and Education, 5(1), 131-140. https://doi.org/10.5937/IJCRSEE1701131B

8. Canovi, M. (2019). Resistance to agritourism diversification: An analysis of winery owners' identities. Tourism Management Perspectives, 32, 100566. https://doi.org/10.1016/j.tmp.2019.100566

9. Carmichael, B. A. (2005). Understanding the wine tourism experience for winery visitors in the Niagara Region, Ontario, Canada. Tourism Geographies, 7(2), 185-204. https://doi.org/10.1080/14616680500072414

10. Choo, H., \& Petrick, J. F. (2014). Social interactions and intentions to revisit for agritourism service encounters. Tourism Management, 40, 372-381. http://dx.doi.org/10.1016/j.tourman.2013.07.011

11. Contini, C., Scarpellini, P., \& Polidori, R. (2009). Agri-tourism and rural development: The Low-Valdelsa case, Italy. Tourism Review, 64(4), 27-36. https://doi.org/10.1108/16605370911004557

12. Daugstad, K., \& Kirchengast, C. (2013). Authenticity and the pseudo-backstage of agritourism. Annals of Tourism Research, 43, 170-191. https://doi.org/10.1016/j.annals.2013.04.004

13. Dimitrovski, D., Todorovic A., \& Valjarevic A. (2012). Rural tourism and regional development: Case study of development of rural tourism in the region of Gruža, Serbia. $\begin{array}{llll}\text { Procedia environmental } & \text { 288-297. }\end{array}$ https://doi.org/10.1016/j.proenv.2012.03.028

14. Doh, K., Park, S., \& Kim, D. Y. (2017). Antecedents and consequences of managerial behavior in agritourism. Tourism Management, 61, 511-522. https://doi.org/10.1016/j.tourman.2017.03.023

15. Dubois, C., Cawley, M., \& Schmitz, S. (2017). The tourist on the farm: A 'muddled' image. Tourism Management, 298-311. https://doi.org/10.1016/j.tourman.2016.08.016

16. Embacher, H. (1994). Marketing for Agri-tourism in Austria: Strategy and realisation in a highly developed tourist destination. Journal of Sustainable Tourism, 2(1-2), 61-76. https://doi.org/10.1080/09669589409510684

17. Flanigan, S., Blackstock, K., \& Hunter, C. (2014). Agritourism from the perspective of providers and visitors: a typology-based study. Tourism Management, 40, 394-405. https://doi.org/10.1016/j.tourman.2013.07.004

18. Gao, J., Barbieri, C., \& Valdivia, C. (2014). Agricultural landscape preferences: Implications for agritourism development. Journal of Travel Research, 53(3), 366-379. https://doi.org/10.1177/0047287513496471

19. Giaccio, V., Giannelli, A., \& Mastronardi, L. (2018). Explaining determinants of agritourism income: Evidence from Italy. Tourism Review, 73(2), 216-229. https://doi.org/10.1108/TR-05-2017-0089

20. Govindasamy, R., \& Kelley, K. (2014). Agritourism consumers’ participation in wine tasting events: An econometric analysis. International Journal of Wine Business Research, 26(2), 120-138. https://doi.org/10.1108/IJWBR-04-2013-0011

21. Hegarty, C., \& Przezborska, L. (2005). Rural and agri-tourism as a tool for reorganising rural areas in old and new member states - a comparison study of Ireland and Poland. International Journal of Tourism Research, 7(2), 63-77. https://doi.org/10.1002/jtr.513

22. Hill, R., Loomis, J., Thilmany, D., \& Sullins, M. (2014). Economic values of agritourism to visitors: a multi-destination hurdle travel cost model of demand. Tourism Economics, 20(5), 1047-1065. https://doi.org/10.5367/te.2013.0323 
23. Horng, J. S., \& Tsai, C. T. (2012). Culinary tourism strategic development: An AsiaPacific perspective. International Journal of Tourism Research, 31(1), 74-85. https://doi.org/10.1002/jtr.834

24. Koutsouris, A., Gidarakou, I., Grava, F., \& Michailidis, A. (2014). The phantom of (agri) tourism and agriculture symbiosis? A Greek case study. Tourism Management Perspectives, 12, 94-103. http://dx.doi.org/10.1016/j.tmp.2014.09.001

25. Lapan, C., \& Barbieri, C. (2014). The role of agritourism in heritage preservation. Current Issues in Tourism, 17(8), 666-673. https://doi.org/10.1080/13683500.2013.849667

26. Mandarić, M., Milićević, S., \& Sekulić, D. (2017). Traditional Values in the Function of Promotion of Šumadija and Pomoravlje as rural tourism Destinations. Economics of Agriculture, 64(2), 787-803. https://doi.org/10.5937/ekoPolj1702787M

27. McGehee, N. G. (2007). An agritourism systems model: a Weberian perspective. Journal of Sustainable Tourism, 15, 111-124. https://doi.org/10.2167/jost634.0

28. McGehee, N. G., \& Kim, K. (2004). Motivation for agri-tourism entrepreneurship. Journal of Travel Research, 43(2), 161-170. https://doi.org/10.1177/0047287504268245

29. McGehee, N. G., Kim, K., \& Jennings, G. R. (2007). Gender and motivation for agritourism entrepreneurship. Tourism Management, 28, 280-289. https://doi.org/10.1016/j.tourman.2005.12.022

30. Mihailović, B., Simonović, Z., \& Brzaković, T. (2018). Potencijali i perspektiva poljoprivrede i prehrambene industrije grada Smedereva [Resources and perspective of agriculture and food industry of the city of Smederevo]. Anali Ekonomskog fakulteta $u$ Subotici, 54(39), 59-74.

31. Nickerson, N. P., Black, R. J., \& McCool, S. F. (2001). Agritourism: motivations behind farm/ranch business diversification. Journal of Travel Research, 40, 19-26. https://doi.org/10.1177/004728750104000104

32. Nisonger, T. E. (2000). Use of the journal citation reports for serials managementin research libraries: An investigation of the effect of self-citation on journalrankings in library and information science and genetics. College \& Research Libraries, 61(3), 263275. https://doi.org/10.5860/crl.61.3.263

33. Ollenburg, C., \& Buckley, R. (2007). Stated economic and social motivations for farm tourism operators. Journal of Travel Research, 45(4), 444-452. https://doi.org/10.1177/0047287507299574

34. Petrović, M. D., Gelbman, A., Demirović, D., Gagić, S., \& Vuković, D. B. (2017). The examination of the residents' activities and dedication to the local community-an agritourism access to the subject. Journal of the Geographical Institute "Jovan Cvijic", SASA, 67(1), 37-52. https://doi.org/10.2298/IJGI1701037P

35. Phillip, S., Hunter, C., \& Blackstock, K. (2010). A typology for defining agritourism. Tourism Management, 31(6), 754-758. https://doi.org/10.1016/j.tourman.2009.08.001

36. Pjanić, M., Vuković, B., \& Mijić, K. (2018). Analysis of the Market Concentration of Agricultural Enterprises in AP Vojvodina. Strategic Management, 23(4), 40-45. https://doi.org/10.5937/StraMan1804040P

37. Rong-Da Liang, A. (2017). Considering the role of agritourism co-creation from a service-dominant logic perspective. Tourism Management, 61, 354-367. http://dx.doi.org/10.1016/j.tourman.2017.02.002

38. Simonović, Z., Mihailović, B., \& Janković, M. (2017). Focusing of Agricultural Production in Serbia and its Sustainable Development. Economics of Sustainable Development, 1(1), 19-32.

39. Tew, C., \& Barbieri, C. (2012). The perceived benefits of agritourism: The provider's $\begin{array}{llll}\text { perspective. Tourism } & \text { 33(1), 215-224. }\end{array}$ https://doi.org/10.1016/j.tourman.2011.02.005 
40. Vuković, P. (2017). Character and dynamics of development rural tourism in the Republic of Serbia. Ekonomika, 53-60. https://doi.org/10.5937/ekonomika1704053V

41. Wicks, B., \& Merrett, C. (2003). Agritourism: an economic opportunity for Illinois. Rural Research Report, 14(9), 1-8.

42. Zhang, X., Cai, L., \& Harrill, R. (2009). Rural Tourism Research in China: 1997-2006, Tourism Analysis, 14(2), 231-39. https://doi.org/10.3727/108354209789116583 